\title{
Consequences of Fathers' Parental Leave Use: Evidence from Sweden
}

\author{
ANN-ZOFIE DUVANDER, Ph.D., Associate Professor ${ }^{1}$, Senior Researcher ${ }^{2}$ \\ Sociology Department, Stockholm University ${ }^{1}$ and Swedish Social Insurance \\ Agency $^{2}$
}

\author{
ANN-CHRISTIN JANS, Ph.D., Senior Researcher \\ Swedish Public Employment Service
}

\begin{abstract}
Fathers' parental leave use is often assumed to affect gender equality both at home and in the labour market. In the home, fathers' parental leave is expected to improve father-child contact later on in the child's life. In this study the associations between fathers'parental leave use and further adaption to family life and contact with children are investigated. The first research question is whether fathers who have used parental leave are more likely to have shorter working hours during their children's first years compared to fathers who have not used the leave. The second question is whether the contact between separated fathers and their children is associated with the father's previous parental leave use. We use a survey carried out in 2003 with a sample of approximately 4000 parents of children born in 1993 and 1999. The findings indicate that fathers' parental leave is associated with both shorter working hours later in the child's life and more contact between separated fathers and their children.
\end{abstract}

Keywords: Fathers, parental leave, working hours, contact with children, separations, family policy, Sweden

\section{Introduction}

In Swedish politics there is a strong and rarely questioned goal that fathers' use of parental leave should increase. Also in most research fathers' parental leave use is seen as a positive outcome. The reasons for the positive view of father's parental leave are often connected to gender equality (Joshi 1998). Other aspects concern the fertility level (Duvander and Andersson 2006; Olah 2003), family stability (Olah 2003), health (Månsdotter 2006) and fathers' opportunities for personal development. In fact, fathers often motivate leave with the desire to be off work for some time (Björnberg 1998; Lammi-Taskula 2007). However, one may argue that the most important reason for fathers' leave is children's right to time with both parents (Sundström and Duvander 2002). At least in Sweden, this aspect is increasingly in focus. It is not only seen as positive for the father to get the opportunity to spend time with his child, but it is also seen as a value for the child to get access to both parents. Very little knowledge exists on whether the father's parental leave leads to more contact with his child later in the 
child's life, but there is strong support that paternal involvement will lead to various positive outcomes for children (Sarkadi et al. 2008).

In this study, we attempt to investigate the association between fathers' use of parental leave and further adaption to family life and contact with children. Even if causality cannot be concluded in this study we argue that it is valuable knowledge to establish whether these associations exist. Paternal engagement with children may matter not just for this specific relationship but may have consequences for the rest of family life and household work (Coltrane 1996; Plantin et al. 2003). Therefore it is of great policy relevance to establish any association between desired outcomes and fathers' parental leave use.

We will start with a brief introduction to Swedish parental leave policy, and then mention some relevant earlier literature on the subject and the data we use. Thereafter we will describe the results of the study. We discuss the results at the end of the report.

\section{Swedish parental leave}

The Swedish parental leave policy was introduced in 1974 and was one of the political reforms transforming Swedish society from being a society based on a male-breadwinner model to one based on a dual-earner model. Today, almost as many women as men participate in the labour market. However, mothers still work part time to a large degree. Almost half of all women with children in ages 3-6 work part time (Statistics Sweden 2007).

Parental leave was originally 6 months, but the length of the leave was gradually extended during the 1980s until it was 12 months in 1989. The leave can be used up until the child's $8^{\text {th }}$ birthday but the major part of the leave is normally used during the child's first years. In 2002 the leave was extended by another month and the leave is currently 13 months. For three additional months of parental leave earnings are replaced at a low flat rate. The 13 months today replace 80 percent of earlier income up to a relatively high ceiling.

The parental leave benefit has to be used for 7 days a week for the parent to be replaced at 80 percent. However, it is also possible to extend the leave period by accepting a lower replacement. One may for example use $3 / 4$ replacements for every day away from work and in this way extend the leave period by $1 / 4$. This is a very common strategy used especially by mothers. Typically women use about 16 months of leave away from work and men 2 months, but there are large variations (Berggren 2004).

Parents with no earnings during the six months preceding childbirth receive only the low flat rate that applies to the three additional months. Less than 1 percent of all Swedish-born fathers receive parental leave at flat rate (referring to fathers of children born in 1999). The low number indicates that most fathers who are not established in the labour market do not use the leave (Duvander and Eklund 2006). 
Fathers used a very small share of the parental leave during the 1970s, and this share has thereafter increased slowly to today's 20 percent of the leave days used (see Figure 1). The skewed division between men and women has been a matter of political concern, and as a result, in 1995 one month of the parental leave was reserved for each parent. This meant that it was impossible for one parent (i.e. the mother) to use the whole leave period, but the other parent had to use one month for it not to be forfeited. After the introduction of this use-or-lose 'daddy-month' the share of fathers who used the leave increased. In 2002 one additional month was reserved for each parent. The result of the second 'daddy-month' was an increase in parental leave days used by the father. Today more than 85 percent of eligible fathers use some leave during the child's first 7 years. During the first 2 years approximately 72 percent of fathers use some leave which is comparable to the figures in this study.

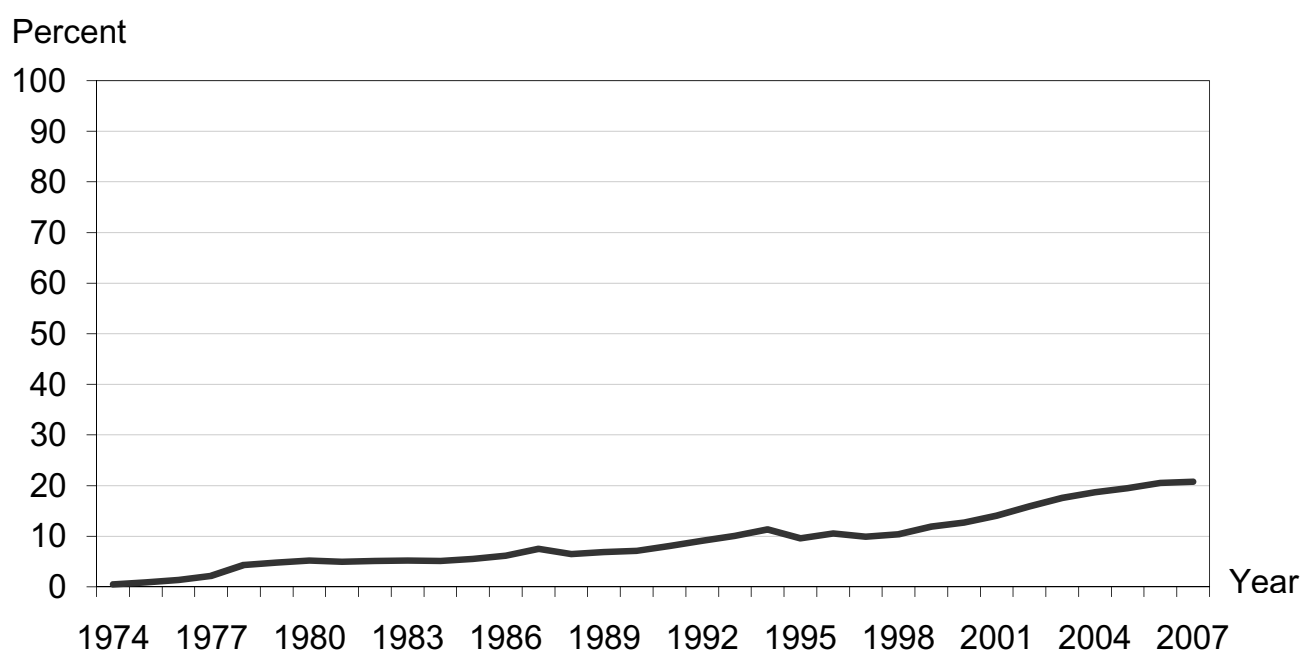

Figure 1. Men's share of all parental leave days used 1974-2007.

Thus, Swedish fathers may be seen as involved in childcare from an early stage. Another indicator of early involvement is that fathers also take a considerable share of days at home to care for sick children. Leave for sick children can be used up to the child's $12^{\text {th }}$ birthday with similar benefit levels as for parental leave. Up to 60 days a year can be used for every child but the average is much lower. Care for sick children may be taken as an indication of father-child contact. Fathers use approximately 36 percent of all days at home.

\section{Earlier research}

Paternal involvement may have various consequences for children and there are various reasons why father involvement may matter (Pleck 1997; 2007). A large body of research has measured different outcomes, such as cognitive development, psychological health, parent-child relationship, educational achievement and behavioural problems. 
Studies have measured father involvement in various ways and the follow-up period varies considerably between studies. A recent systematic review concludes that there is evidence that fathers' engagement positively influences children's social, behavioural and psychological outcomes (Sarkadi et al. 2008). Some studies also focus on the difference between father and mother involvement and that the gendered effects may vary between children in different ages (Hango 2007; Gaertner et al. 2007).

Also, evidence on separated parents emphasizes the role of co-parenting (i.e. increased father involvement in most cases) on fathers' continued involvement after separation (Carlson et al. 2008). The situation of separated parents needs a specific framework when investigating continued father involvement (Spillman et al. 2004). For example, the qualitative dimensions of contact may vary by structure and individual characteristics (King et al. 2004).

The large number of studies on the subject mirror an upswing in interest in fathers, based on their fast changing role, especially in relation to children, but also in relation to the rest of the family life. The process of change may look different in different countries. In Sweden, fathers' parental leave use is one reason to expect that fathers' involvement is relatively large. Even if focus still lies on the mother-child relation (Premberg et al. 2008), fathers often recognize their importance and state that they would like more time with children (Hallberg et al. 2007; Duvander and Berggren 2003).

It is not possible to directly apply the findings regarding paternal involvement to the consequences of fathers' parental leave use. The reason is that parental leave is a relatively short period and it is not certain that this period is intrusive enough to actually affect the long-term contact between father and child (Lamb et al. 1983). For instance, a small American study found some long-term effect of fathers' short leaves on fathers' later child care tasks, but not on child responsibility or time spent with children (Seward et al. 2006).

A relevant Swedish study on fathers' parental leave and future contact between father and child is a study by Ekberg et al. (2005). They investigate the effect of the first 'daddy-month' and find strong short-term effects measured as an increase in fathers using parental leave. More interestingly, they also investigate long-term effects by looking at fathers' care of sick children. The study shows that the increase in fathers' parental leave use does not correspond to an increase in leave for care of sick children. This could be taken as indicating that fathers' leave may have modest effects on future behaviour.

\section{This study}

In this study we investigate two possible associations with fathers' use of parental leave. They can be stated in the following research questions: 
1. Will fathers who have used parental leave have shorter working hours than other fathers?

The idea is that fathers who use parental leave will adapt to the new family situation and work shorter hours as a continuation of such an adaption. We of course do not know whether fathers with shorter working hours spend more time with children, but this is a likely assumption regarding working hours of fathers with small children.

2. Will separated fathers who have used parental leave have more frequent contact with their children they do not live with in comparison to fathers who did not use parental leave?

Our hypothesis is that fathers who have used parental leave will have created closer bonds to their child/children and that they will maintain these bonds even if they separate from the child's mother and do not live together with the child anymore.

\section{Data}

The data is based on a survey that Statistics Sweden conducted for the National Social Insurance Board in 2003 (Duvander and Berggren 2003). The sample consists of 4000 parents of children from the birth cohorts of 1993 and 1999 who still live with their children. The requirement of residing with the child gives an overrepresentation of mothers in the sample. The survey examined how parents combined work and children and how they evaluated their everyday situation. The survey was conducted by telephone interviews and the response rate was 79.8 percent. To the survey responses were added register data on income, education, parental leave use and other social insurance data (see for example Duvander and Berggren 2003).

In the survey parental leave was measured both by registered parental leave benefits and by respondents' answers to the question of how long leave s/he and her/his partner took respectively. In this study we use the answer from the respondents, which for men corresponds quite closely to the number of registered parental leave benefit days (Berggren, 2004).

The first research question is analyzed by studying the male respondents' estimation of their work hours, as well as female respondents' estimation on their partners' work hours. The results apply to fathers who still live with their child and the child's mother.

The second research question is analyzed by studying the female respondents' estimation of how often their child meets their father that they no longer live with. The results obviously apply to fathers who no longer live with their children. As the survey was conducted in 2003 the answers apply to children approximately 3 and 10 years old. The overwhelming majority of these fathers have lived with their child earlier as it is very uncommon in Sweden to start parenthood as a single. 
These responses may be coloured by norms about fatherhood that may differ by groups, such as mothers and fathers, separated and co-residing parents and parents with different educational background (see for example Andrews et al. 2004 for differential parental norms). Nevertheless, the quantitative quality of the responses indicate high reliability.

Regarding the estimation of separated fathers' contact it would have been preferable to use also the responses of fathers not living with their children, but these were not available in the data used. Unfortunately, separated fathers who were living with their children and responded about contact with the non co-resident mother, were too few to use in the analysis.

As control variables we use register information on the age and education of parents and respondents' answers about household composition, as well as access to flexible work hours by fathers and the extent of work of mothers.

\section{Findings}

The first part of the study investigates fathers who still live with the mother of their child and the way fathers adapt to the family situation. In the next part we look at fathers who have separated from the mother and don't live with their children anymore. Figure 2 shows the parental leave use for the two groups of fathers, that is, the co-residing and separated fathers at the time of the interview.

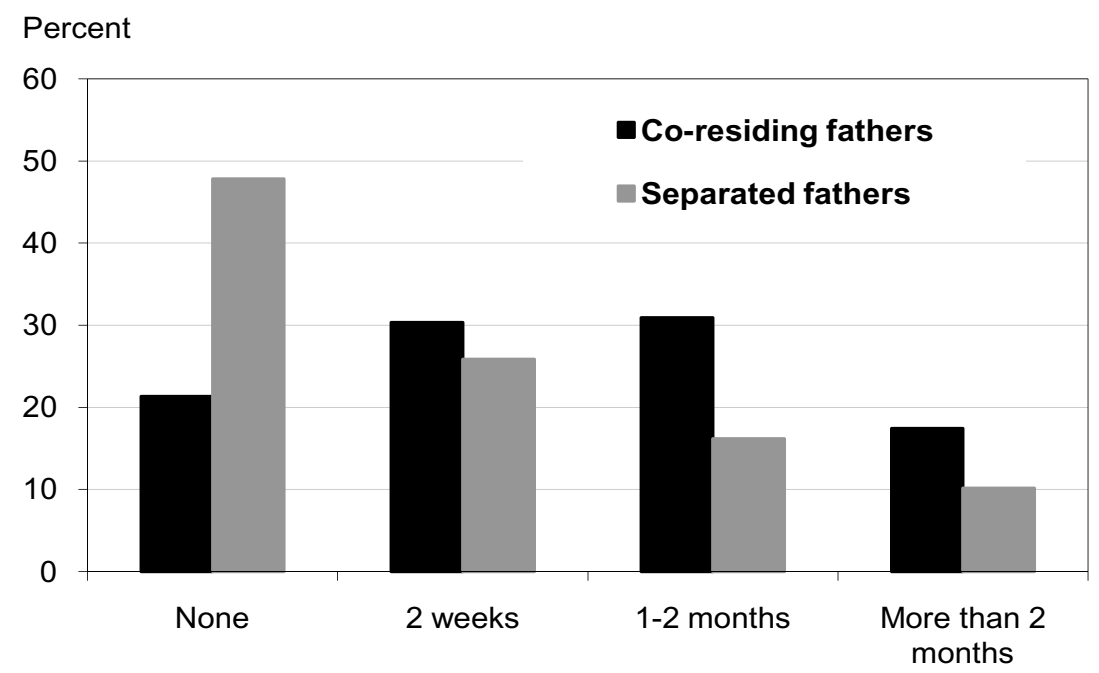

Figure 2. Parental leave used by co-residing and separated fathers. 
There is a large difference in parental leave use between fathers that are still co-residing with the child and the child's mother, and fathers that have separated. Separated fathers used the parental leave to a much smaller extent than fathers who were still living together with the child and the child's mother. In line with this finding, earlier research has found that in couples where fathers use parental leave, separations happen less frequently (Olah 2003). One interpretation is that division of parental leave strengthens unions or that division of childcare reduces stress in the union. It may however also be a selection effect. Unfortunately both the present and earlier studies use too small samples to investigate the details regarding the association between parental leave and separation. For example, it would be necessary to know more about the relationship within subgroups of parents, such as different number of children and different socioeconomic status between parents.

Our first research question is the association between the use of parental leave and the subsequent working hours by fathers. We therefore restrict our analysis to fathers who work. Most of these fathers work full time (approximately 40 hours per week) or even more when the children are small (Table 1). The mean number of hours among the fathers in this study is almost 43 hours per week. We find that fathers who have used parental leave work fewer hours per week than fathers who did not use the leave. We also find a negative correlation between length of leave and subsequent working hours.

Table 1. Fathers' mean number of working hours per week by parental leave use in 2003.

\begin{tabular}{lc}
\hline Parental leave use & Working hours \\
\hline None & 44.7 \\
1-14 days & 43.3 \\
15-60 days & 42.3 \\
More than 60 days & 40.9 \\
AII & $\mathbf{4 2 . 7}$ \\
\hline
\end{tabular}

To analyze the association between parental leave use and the number of hours worked we first use ordinary least square models, controlling for year of birth of the child, whether this child is the youngest child in the household, number of children in the household, age of the father and fathers' and mothers' education. In a second model we add indicators of whether the father had flexible working hours and whether the mother worked full time. The results from these regressions are shown in Table 2. In both models we find statistically significant results indicating that fathers who used parental leave work significantly fewer hours per week compared to fathers not using the leave. In addition, the longer the leave fathers use, the less hours they work. The association may thus be seen as linear. The controls of present work situation in the second model do not significantly change the main results or the coefficients. Despite the low level of explanation (measured adjusted R-square) 
indicating that also other factors are important in explaining fathers' work hours, the correlation between parental leave use and subsequent work hours is strong and stable.

Table 2. Ordinary least square regressions, fathers' weekly work hours.

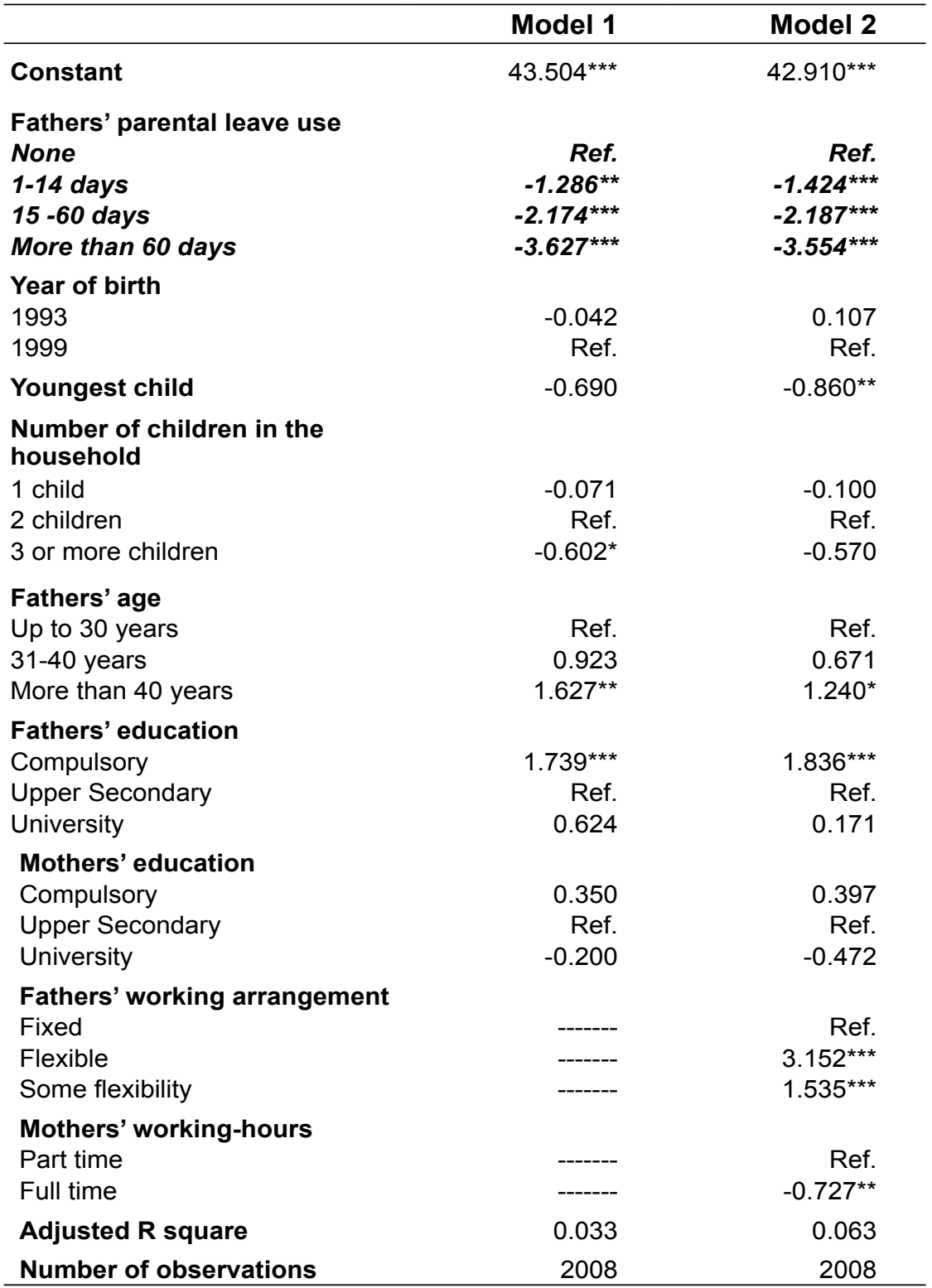

${ }^{* * *}=$ significant on the 1 percent level,

** $=$ significant on the 5 percent level,

* $=$ significant on the 10 percent level. 
Furthermore, we find that work hours increase with fathers' age but are lower for fathers with compulsory education. Fathers with university education work somewhat longer hours and in the second model it is clear that flexibility in work hours is correlated with longer work hours. The fathers with high education and flexible work hours are to a large extent the same fathers. We also find that fathers work shorter hours if the mother works full time. There is a tendency that fathers work fewer hours if there are three or more children in the household and if the child he has taken leave for is the youngest in the family.

The second research question that we are interested in is if separated fathers who have used parental leave will have more frequent contact with their child compared to fathers who used less or did not use parental leave at all. For this part of the analysis we focus on the subsample of children with separated parents and among them, the children who live with their mothers. Out of the whole sample of children, 18 percent lived with one parent at the time of the survey. The majority of these children lived with their mothers, constituting 83 percent of all children living with one parent.

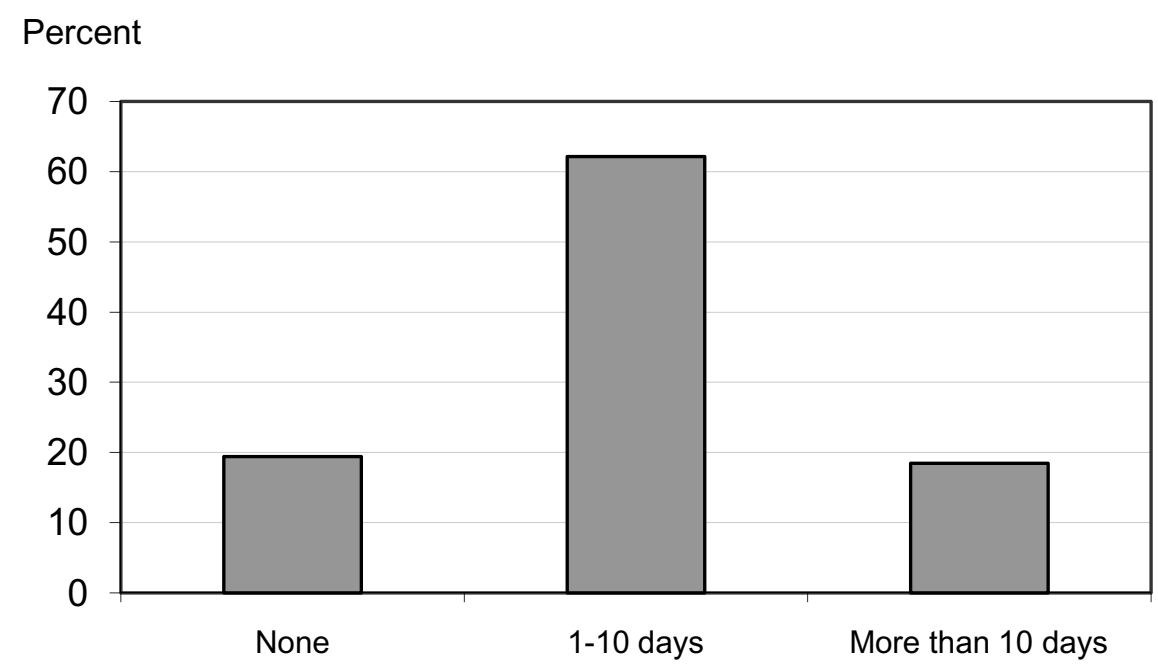

Figure 3. Separated fathers' monthly contact with their children in 2003.

The most common pattern is that fathers meet their children every second weekend and some additional day(s) per week, amounting to around 4-10 days depending on how long the weekend is. However, in nearly 20 percent of the cases, the mothers respond that the fathers did not meet their children every month or at all (see Figure 3).

Table 3 gives the mean number of contact days per month with respect to separated fathers' use of parental leave. It is clear that fathers who used parental leave met their children more often than fathers who did not use the leave. Fathers who did not use the leave met their children on average 5 days per month, while fathers who used 1 to 2 
months of leave met their children on average 7 days per month. However, the fathers who used even longer leave did not, on average, meet their children more often.

Table 3. Separated fathers' mean number of contact days per month by parental leave use in 2003.

\begin{tabular}{lc}
\hline Parental leave use & Contact days per month \\
\hline None & 4.6 \\
$1-14$ days & 5.4 \\
$15-60$ days & 6.9 \\
More than 60 days & 6.5 \\
\hline AlI & $\mathbf{5 . 4}$ \\
\hline
\end{tabular}

To analyze to what extent the use of parental leave matters for the contact between separated fathers and their children we used a multinomial logistic model because the number of contact days is not continuous. Instead we view three groups as qualitatively different. The dependent variable is therefore divided into three mutually exclusive groups; one for fathers who have no contact at all with their children, one for fathers who meet their children 1 to 10 days per month (the most common state) and one for fathers with more frequent contact. In the models we control for year of birth of the child, whether the child is the youngest child in the household, number of children in the household, age of the mother and if the mother was living with new partner.

The result from the logistic regression is shown in Table 4. The results show that separated fathers who have used more than two weeks of parental leave were significantly more likely to have more frequent contact with their child after the separation compared to fathers who did not use any leave. 
Table 4. Multinominal logistic regression for separated fathers' contact with their children.

\begin{tabular}{|c|c|c|}
\hline & $\begin{array}{l}1-10 \text { days of contact/month } \\
\text { relative to no contact }\end{array}$ & $\begin{array}{l}\text { More than } 10 \text { days/month } \\
\text { relative to no contact }\end{array}$ \\
\hline Constant & $0.871^{*}$ & 0.509 \\
\hline $\begin{array}{l}\text { Fathers' parental leave use } \\
\text { None } \\
1-14 \text { days } \\
15 \text { - } 60 \text { days } \\
\text { More than } 60 \text { days }\end{array}$ & $\begin{array}{r}\text { Ref. } \\
0.776^{* *} \\
3.294^{\star * *} \\
1.443^{\star *}\end{array}$ & $\begin{array}{r}\text { Ref. } \\
0.195 \\
3.532^{* * *} \\
1.614^{\star *}\end{array}$ \\
\hline $\begin{array}{l}\text { Year of birth } \\
1993 \\
1999\end{array}$ & $\begin{array}{l}0.559 \\
\text { Ref. }\end{array}$ & $\begin{array}{l}0.800^{*} \\
\text { Ref. }\end{array}$ \\
\hline Youngest child & 0.600 & 0.659 \\
\hline $\begin{array}{l}\text { Number of children in the } \\
\text { household } \\
1 \text { child } \\
2 \text { children } \\
3 \text { or more children }\end{array}$ & $\begin{array}{r}-0.935^{* *} \\
\text { Ref. } \\
-0.847^{* \star}\end{array}$ & $\begin{array}{r}-1.166^{* *} \\
\text { Ref. } \\
-1.240^{* * *}\end{array}$ \\
\hline $\begin{array}{l}\text { Mothers' age } \\
\text { Up to } 30 \text { years } \\
31-40 \text { years } \\
\text { More than } 40 \text { years }\end{array}$ & $\begin{array}{r}\text { Ref. } \\
-0.631^{*} \\
-0.746\end{array}$ & $\begin{array}{r}\text { Ref. } \\
0.137 \\
-1.813^{* *}\end{array}$ \\
\hline Mother has a new partner & 0.258 & -0.657 \\
\hline Number of observations & & 433 \\
\hline Log likelihood value & & -356.1 \\
\hline
\end{tabular}

${ }^{* * *}=$ significant on the 1 percent level,

** $=$ significant on the 5 percent level,

* $=$ significant on the 10 percent level.

The reference category is children with no contact at all with their fathers, children that were born in 1999, living in a household with one other child, with mothers aged 19-30 years using 361 to 451 days of parental leave and with fathers using no parental leave at all.

The results do not show that fathers who used the longest leave were most likely to have most frequent contact. Instead these fathers were somewhat less likely to have frequent contact compared to the group of fathers who had used 2 weeks to 2 months of leave. This indicates that the association is not linear; at long leaves the rate of increase is reduced. It may be that the ones using long leaves stand out in other respects and that long leaves do not simply signify closer bonds to children. For example, some of the fathers who used long leaves may have done so for labour market reasons. Similar results regarding the association between parental leave length and continued childbearing have been found by Duvander and Andersson (2006). They also found that the group that used very long leaves also had on average lower income. In the present study we cannot support such findings, as the small sample of separated fathers restricts us from drawing any conclusions here. 
The control variables show that children with one sibling seem to meet their fathers more often than children with no or more than one sibling. Children with older mothers seem to meet their fathers more often than children with younger mothers, and children of mothers who have met a new partner seem to meet their fathers less often.

\section{Conclusion}

As stated, these results indicate a positive association between fathers' parental leave use and continued father-child contact. Fathers who have used parental leave work shorter hours and also have more contact with their children in case of non co-residence. A plausible interpretation is that parental leave strengthens bonds between father and child and that these bonds remain even when the father goes back to work or in case of separation.

However, we would like to be cautious about such causal interpretations of the results and point out that a selection effect is just as likely. It may be that parental leave as such does not change the situation, but that it is the most child-oriented fathers that use the leave and also have shorter hours or maintain contact (and would have done so even if they did not have the possibility to use leave). It may be that fathers with shorter working hours had shorter working hours also before using parental leave and even before becoming fathers. It may be that fathers who have little contact after separation had no greater contact while living with the child. A more sophisticated analysis of the subject would in various ways disentangle the question of causality and selection.

A related issue is that of fathers' reasons for using parental leave. If the motive for using leave is to strengthen the father-child contact, the results from this study are expected. Likewise, a positive effect on long-term gender-equality would be expected if the motive was to share child care in the household. But if the motive for using the leave is to be off work for an extended period, or to pursue any aspect of selffulfilment, a long-term effect on the father-child contact is not as likely. Therefore more information on fathers' motives, expectations and experiences regarding parental leave would be useful.

The association between fathers' parental leave and shorter work hours as well as more contact with non co-resident children indicate the importance of the parental leave regulations. In Sweden parental leave available to fathers and the 'daddy months' reserved for fathers are crucial policies encouraging children's access to their fathers. It is an important finding that fathers who start off by being accessible to their children tend to continue being so. 


\section{References}

Andrews, A. B., I. Luckey, E. Bolden, J. Whiting-Fickling and K. A. Lind. 2004. Public perceptions about father involvement: results of a statewide household survey. Journal of Family Issues 25(5): 603-633.

Berggren, S. 2004. Flexibel föräldrapenning - hur mammor och pappor använder föräldraförsäkringen och hur länge de är föräldralediga [A flexible parental leave: how the parental leave is used by mothers and fathers and how long parents are on leave]. The National Social Insurance Board (RFV) Analyserar 2004:14.

Björnberg, U. 1998. Family orientation among men: A process of change in Sweden. In Women, Work and the Family in Europe, edited by Drew, E., E. Emerek and E. Mahon, pp. 200-207. London: Routledge.

Carlson, M. J., S. S. McLanahan \& J. Brooks-Gunn. 2008. Co-parenting and nonresident fathers' involvement with young children after a non-marital birth. Demography 45(2): 461-488.

Coltrane, S. 1996. Family man: fatherhood housework and gender equity. New York: Oxford University Press.

Duvander, A-Z. and G. Andersson. 2006. Gender equality and fertility in Sweden: A study on the impact of the father's uptake of parental leave on continued childbearing. Marriage and Family Review 39: 121-142.

Duvander, A-Z. and S. Berggren. 2003. Family Assets - Time and Money. In Social Insurance in Sweden 2003, edited by B-M. Andersson, pp. 11-67. The National Social Insurance Board (RFV), Stockholm.

Duvander, A-Z. and S. Eklund. 2006. Utrikesfödda och svenskfödda föräldrars föräldrapenninganvändande [Foreign born and Swedish born parents' parental leave use]. In Om välfärdens gränser och det villkorade medborgarskapet, edited by P. de los Reyes. Official government report, SOU 2006:37, pp. 33-68. Stockholm: Fritzes.

Ekberg, J., R. Eriksson and G. Friebel. 2005. Parental leave - A policy evaluation of the Swedish "daddy-month" reform. IZA Discussion Paper, No. 1617. IZA, Bonn.

Gaertner, B. M., T. L. Spinrad, N. Eisenberg \& K. A. Greving. 2007. Parental childrearing attitudes as correlates of father involvement during infancy. Journal of Marriage and Family 69:962-976.

Hallberg, A-C., R. Kristiansson, A. Beckman, K. Petersson, L. Råstam and A. Håkansson. 2007. Fathers and their children's health: a telephone interview study. Acta Pcediatricia 96:1083-1087.

Hango, D. 2007. Parental investment in childhood and educational qualifications: can greater parental involvement mediate the effects of socioeconomic disadvantage? Social Science Research 36: 1371-1390.

Joshi, H. 1998. The opportunity costs of childbearing: More than mothers' business. Journal of Population Economics 11: 161-183.

King, V., K. M. Harris and H. E. Heard. 2004. Racial and ethnic diversity on nonresident father involvement. Journal of Marriage and Family 66: 1-21.

Lamb, M. E., M. Frodi, C-P. Hwang and A.M. Frodi. 1983. Effects of paternal involvement in infant preferences for mothers and fathers. Child Development 54: 450-458. 
Lammi-Taskula, J. 2007. Parental leave for fathers? Gendered conceptions and practices in families with young children in Finland. Dissertation, Research report 166. National research and development centre for welfare and health, Helsinki, Finland.

Månsdotter, A. 2006. Health, economics, and feminism: on judging fairness and reform. Dissertation No. 1013. Department of Public Health and Clinical Medicine, Umeå University, Sweden.

Oláh, L. Sz. 2003. Gendering fertility: Second births in Sweden and Hungary. Population Research and Policy Review 22:171-200.

Plantin, L., S-A. Månsson and J. Kearney. 2003. Talking and doing fatherhood. On fatherhood and masculinity in Sweden and Britain. Fathering 1(1): 3-26.

Pleck, J. H. 1997. Paternal involvement: Levels, sources, and consequences. In The role of the father in child development, edited by M.E. Lamb, pp. 66-103. New York: John Wiley and Sons Incorporation.

Pleck, J. H. 2007. Why could father involvement benefit children? Theoretical perspectives. Applied Development Science 11(4): 196-202.

Premberg, Å., A-L. Hellström and M. Berg. 2008. Experiences of the first year as father. Scandinavian Journal of Caring Sciences 22: 56-63.

Sarkadi, A., R. Kristiansson, F. Oberklaid and S. Bremberg. 2008. Fathers' involvement and children's developmental outcomes: a systematic review of longitudinal studies. Acta Pcediatricia 97: 153-158.

Seward, R.R., D.E. Yeatts, I. Amin and A. Dewitt. 2006. Employment leave and fathers' involvement with children: according to mothers and fathers. Men and Masculinities 8(4): 405-427.

Spillman, J. A., H. S. Deschamps and J. A. Crews. 2004. Perspectives on nonresidential paternal involvement and grief: a literature review. The Family Journal 12(3): 263-270.

Statistics Sweden. 2007. Women and Men in Sweden. Facts and figures 2007. Statistics Sweden.

Sundström, M. and A-Z. Duvander. 2002. Gender division of childcare and the sharing of parental leave among new parents in Sweden. European Sociological Review 18: 433-447. 